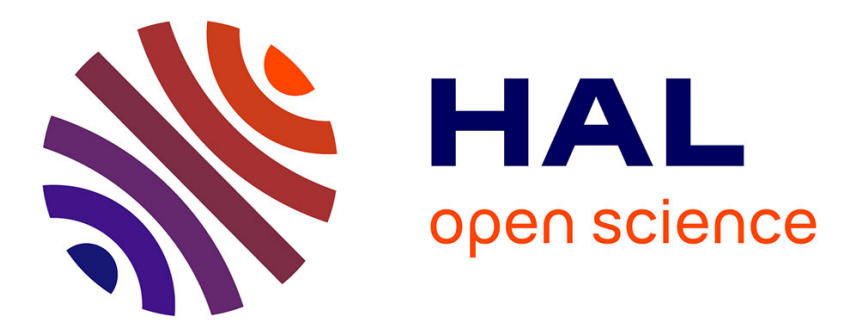

\title{
Do ridge-ridge-fault triple junctions exist on Earth? Evidence from the Aden-Owen-Carlsberg junction in the NW Indian Ocean
}

Marc Fournier, Carole Petit, Nicolas Chamot-Rooke, Olivier Fabbri, Philippe Huchon, Bertrand Maillot, Claude Lepvrier

\section{To cite this version:}

Marc Fournier, Carole Petit, Nicolas Chamot-Rooke, Olivier Fabbri, Philippe Huchon, et al.. Do ridge-ridge-fault triple junctions exist on Earth? Evidence from the Aden-Owen-Carlsberg junction in the NW Indian Ocean. Basin Research, 2008, 20, pp.575-590. 10.1111/j.1365-2117.2008.00356.x . hal-00581775

\section{HAL Id: hal-00581775 \\ https://hal.sorbonne-universite.fr/hal-00581775}

Submitted on 31 Mar 2011

HAL is a multi-disciplinary open access archive for the deposit and dissemination of scientific research documents, whether they are published or not. The documents may come from teaching and research institutions in France or abroad, or from public or private research centers.
L'archive ouverte pluridisciplinaire HAL, est destinée au dépôt et à la diffusion de documents scientifiques de niveau recherche, publiés ou non, émanant des établissements d'enseignement et de recherche français ou étrangers, des laboratoires publics ou privés. 


\section{Do ridge-ridge-fault triple junctions exist on Earth?}

\section{Evidence from the Aden-Owen-Carlsberg junction in the NW Indian Ocean}

Marc Fournier $12^{*}$, Carole Petit $^{2}$, Nicolas Chamot-Rooke 1 , Olivier Fabbri ${ }^{3}$, Philippe Huchon $^{2}$, Bertrand Maillot ${ }^{4}$ and Claude Lepvrier ${ }^{2}$

${ }^{1}$ CNRS, Ecole Normale Supérieure, Laboratoire de Géologie, 24 rue Lhomond, 75005 Paris, France

${ }^{2}$ CNRS, Université Pierre et Marie Curie-Paris 6, UCP, Laboratoire de Tectonique, Case 129, 4 place Jussieu, 75252 Paris, France

3 Université de Franche-Comté, Département de Géosciences, 16 route de Gray, 25030 Besançon, France

${ }^{4}$ CNRS, Université de Cergy-Pontoise, UPMC, Laboratoire de Tectonique, 5 mail GayLussac, Neuville/Oise, 95031 Cergy-Pontoise

* Corresponding author: marc.fournier@upmc.fr

Abstract. The triple junctions predicted to be ridge-ridge-fault (RRF) types on the basis of large scale plate motions are the Azores triple junction between the Gloria Fault and the MidAtlantic Ridge, the Juan Fernandez triple junction between the Chile Transform and the East Pacific Rise, and the Aden-Owen-Carlsberg (AOC) triple junction between the Owen fracture zone (OFZ) and the Carlsberg and Sheba ridges. In the two first cases, the expected RRF triple junction does not exist because the transform fault arm of the triple junction has evolved into a divergent boundary before connecting to the ridges. We here report the results of a marine geophysical survey of the AOC triple junction which took place in 2006 aboard the $R / V$ Beautemps-Beaupré. We show that a rift basin currently forms at the southern end of the OFZ, indicating that a divergent plate boundary between Arabia and India is developing at the triple junction. The connection of this boundary with the Carlsberg and Sheba ridges is not clearly delineated and the triple junction presently corresponds to a widespread zone of distributed deformation. The AOC triple junction appears to be in a transient stage between a former triple junction of the RFF type and a future triple junction of the RRR type. Consequently, the known three examples of potential RRF triple junctions are actually of the RRR type, and RRF triple junctions do not presently exist on Earth. 


\section{Introduction}

Soon after the advent of plate tectonics, researchers have noticed that there should be points where three plates and their boundaries meet. McKenzie and Morgan (1969) explored the potential stability of such triple junctions by predicting the evolutionary behaviour of plate boundaries at the local scale based on the large-scale motions of the plates. The velocityspace representation of local velocities that they developed is still extremely useful in studying these junctions, although almost nowhere can the triple junction evolution be predicted using their assumptions. Part of the problem lies in the assumption that oceanic ridges should spread symmetrically and orthogonally to ridge axis. Even at relatively simple triple junctions, such as the ridge-ridge-ridge (RRR) Rodriguez triple junction in the Indian Ocean, the ridges do not spread orthogonally (Tapscott et al., 1980; Patriat and Parson, 1989; Munschy and Schlich, 1989; Mitchell, 1991; Mitchell and Parson, 1993; Honsho et al., 1996). Another problem with the velocity-space diagram analysis has been that the type of plate boundary at triple junctions is not predictable only from the large-scale plate motions. In the Pacific, the Galapagos and Juan Fernandez junctions have both turned out to contain microplates (Lonsdale, 1988; Klein et al., 2005; Larson et al., 1992; Bird and Naar, 1994; Bird et al., 1998), and in the Atlantic, the Azores and Bouvet junctions correspond to zones of distributed deformation where the three plate boundaries do not meet at a point (Searle, 1980; Luis et al., 1994; Fernandes, 2006; Sclater et al., 1976; Ligi et al., 1997, 1999; Mitchell and Livermore, 1998). Here we investigate the potential stability of ridge-ridge-fault (RRF) triple junctions where one transform fault meets two spreading ridges.

In the oceanic domain, three active examples of RRF triple junctions are known on Earth (Figure 1): (1) the Azores triple junction in the Atlantic Ocean, which connects the Gloria transform fault and the Mid-Atlantic Ridge (Searle, 1980; Argus et al., 1989), (2) the Juan Fernandez triple junction in the Pacific Ocean, which connects the Chile Transform and the East Pacific Rise (Larson et al., 1992), and (3) the Aden-Owen-Carslberg (AOC) triple junction in the NW Indian Ocean, which connects the Owen Fracture Zone (OFZ), the Carlsberg Ridge and the Sheba Ridge (Gordon and DeMets, 1989).

The existence of RRF or RFF triple junctions has also long been inferred from the reconstruction of past plate motions from seafloor magnetic anomalies. Based on reconstructions from Chron 5 to 6, Mitchell et al. (2000) concluded that the Bouvet triple junction had probably been of the RFF type for $10 \mathrm{~m}$. y. Similarly, Dyment (1993) reconstructed the evolution of the Indian Ocean triple junction in the early Tertiary and identified several successive RFF configurations. A RFF configuration has also been 
proposed for the Macquarie triple junction (Falconer, 1972) and the $16^{\circ} 40^{\prime}$ S triple junction in the North Fiji Basin (Lafoy et al., 1990).

Kinematically, in the hypothesis of symmetrical and orthogonal spreading, a RRF triple junction is generally unstable, except in the rare case of two perpendicular ridges (McKenzie and Morgan, 1969). It is supposed to evolve into a RFF triple junction, which is stable if the velocity-space diagram is isosceles or if the two transform faults have the same strike (flat velocity-space diagram; Patriat and Courtillot, 1984). Actually, in each of the previous three active examples, the expected RFF triple junction does not exist because the transform fault arm of the triple junction has evolved into a divergent boundary. In the case of the Azores triple junction, the Gloria Transform ends westwards in the oblique Terceira Rift (Vogt and Jung, 2004). At the Juan Fernandez triple junction, a spreading ridge developed at the western end of the Chile Transform, isolating the Juan Fernandez microplate from the Nazca, Pacific and Antarctic plates (Bird et al., 1998). Here, we investigate the case of the AOC triple junction from marine data acquired aboard the $R / V$ Beautemps-Beaupré in autumn 2006 (AOC cruise). Prior to our survey, little was known about this poorly characterized part of the global plate boundary system. We mapped the triple junction with a Kongsberg-Simrad EM120 deep-water multibeam echo-sounder, complemented by gravity, magnetic and subbottom seismic profiles. Our data reveal that a large rift basin is developing at the southern end of the OFZ, initiating an ultra-slow divergent boundary between Arabia and India. Consequently, none of the Azores, Juan Fernandez or AOC triple junctions is of RRF type.

\section{Geodynamic setting of the AOC triple junction}

In the mouth of the Gulf of Aden, the AOC triple junction connects the Owen fracture zone and the Carlsberg and Sheba ridges (Figure 2). The Carlsberg Ridge, so named by Schmidt (1932) in honour of the brewer who sponsored his oceanographic expeditions, was emplaced in the Early Tertiary between the Seychelles and Indian continental blocks (Norton and Sclater, 1979; Royer et al., 2002). It underwent a three-stage evolution with a fast (halfrate ca. $6 \mathrm{~cm} \mathrm{yr}^{-1}$ ) spreading stage between 61 and $51 \mathrm{Ma}$ (A27-A23), followed by a very slow $\left(<0.6 \mathrm{~cm} \mathrm{yr}^{-1}\right)$ divergence between 39 and $23 \mathrm{Ma}(\mathrm{A} 18-\mathrm{A} 6 \mathrm{~b})$ at the time of collision of India and Eurasia, and by a slow (ca. $1.2 \mathrm{~cm} \mathrm{yr}^{-1}$ ) spreading stage until present (Mercuriev et al., 1996). It is presently characterized by orthogonal accretion at a full rate of $2.2 \pm 0.1 \mathrm{~cm} \mathrm{yr}^{-1}$ in its northwestern part (Merkouriev and DeMets, 2006).

The transition from stage 2 to stage 3 is synchronous with spreading initiation in the eastern Gulf of Aden, where magnetic anomaly 6 (20 Ma) has been identified during the AOC 
cruise at $58^{\circ} \mathrm{E}$. After rifting and break-up of the African continental lithosphere in the Aden rift (Lepvrier et al., 2002; Fournier et al., 2004, 2007; Bellahsen et al., 2006; Petit et al., 2007; Tiberi et al., 2007; Gunnell et al., 2007), the nascent Sheba Ridge, first recognized by Matthews et al. (1967) and Laughton et al. (1970), rapidly propagated westward ( 200 $\mathrm{km} / \mathrm{Ma}$ ), as indicated by the age of the oldest magnetic anomaly identified in the Gulf of Aden at the longitude of 54 ${ }^{\circ} \mathrm{E}$ (An 5D, 17-18 Ma; Leroy et al., 2004; d'Acremont et al., 2006) and $51^{\circ} \mathrm{E}$ (An 5C, $16 \mathrm{Ma}$; Sahota, 1990; Huchon and Khanbari, 2003). Accretion at the Sheba Ridge is presently oblique at a poorly constrained full rate of about $2.5 \mathrm{~cm} \mathrm{yr}^{-1}$ in its easternmost end.

The OFZ and the Dalrymple Trough mark the boundary between the Arabian and Indian plates (Figure 2). This $\sim 700 \mathrm{~km}$ long fault was surveyed in the early sixties by the H.M.S. Owen and the H.M.S. Dalrymple and subsequently named by Matthews (1966). The OFZ was early recognized by Wilson (1965), in his seminal article on transform faults, as a type example of ridge-trench transform fault that transformed the India-Somalia divergent motion along the Carlsberg Ridge (constructive plate boundary) into the India-Eurasia convergent motion in the Himalayan collision zone (destructive boundary). Physiographically, the India-Arabia boundary consists in a topographic ridge with a curved shape in map view named the Owen Ridge (Whitmarsh et al., 1974). The Owen Ridge is bounded on its eastern side by the OFZ. From correlations of seismic reflection profiles with DSDP Leg 23 borehole data, Whitmarsh et al. (1974) dated the uplift of the Owen Ridge as Early Miocene (see also Mountain and Prell, 1990). This age coincides with the rifting to spreading transition in the eastern Gulf of Aden. The OFZ terminates northwards into the Dalrymple Trough (McKenzie and Sclater, 1971), which consists of two sub-basins, a long and narrow basin with a half-graben structure to the south and a rhomboedric-shaped pullapart basin to the north (Minshull et al., 1992; Edwards et al., 2000; Gaedicke et al., 2002a, 2002b; Ellouz-Zimmermann et al., 2007). Oblique extensional features observed on seismic profiles are compatible with right-lateral motion and a minimum total extension of $5-7 \mathrm{~km}$ was estimated across the Dalrymple Trough (Edwards et al., 2000). Southwards, the OFZ joins the Carlsberg and Sheba ridge system at the AOC triple junction (Fournier et al., 2001). The segment of the OFZ running southward from the Dalrymple Trough to the latitude of $15^{\circ} \mathrm{N}$ is characterized by a low seismic activity (Figure 2). Further south, the OFZ is seismically quiet for about $250 \mathrm{~km}$. In this area, the Arabia-India plate boundary is not delineated by a well-defined seismic zone. Earthquake focal mechanisms indicate right-lateral slip along the active segment of the OFZ (Sykes, 1968; Quittmeyer and Kafka, 1984; Gordon 
and DeMets, 1989), which implies that Arabia is currently moving northward more rapidly than India with respect to Eurasia. Recently, we used three independent datasets (multibeam bathymetry, earthquakes focal mechanisms and space geodesy) to demonstrate that the OFZ is a pure transform fault that closely follows a small circle centred on a nearby pole of rotation (Fournier et al., 2008). The OFZ is an ultra-slow plate boundary with a rate of motion estimated at $2 \mathrm{~mm} \mathrm{yr}^{-1}$ in NUVEL-1 (DeMets et al., 1990, 1994) and re-evaluated at 3$4 \mathrm{~mm} \mathrm{yr}^{-1}$ from GPS data (Reilinger et al., 2006; Fournier et al., 2008).

Several global and regional plate-motion models allow us to build a velocity-space diagram for the AOC triple junction (DeMets et al., 1990; 1994; Jestin et al., 1994; Fournier et al., 2001; Sella et al., 2002; Kreemer et al., 2004; Reilinger et al., 2006; Vigny et al., 2006; Nocquet et al., 2006). Among these models, some predict a null or left-lateral motion along the OFZ and therefore are not acceptable (Jestin et al., 1994; Sella et al., 2002; Kreemer et al., 2004; Vigny et al., 2006). The other ones can be used to estimate the mean rates and azimuths of motion between Somalia and India and Somalia and Arabia, and associated standard errors (Figure 3). The corresponding velocity-space diagram is almost flat because the spreading rates and azimuths along the eastern Sheba and western Carlsberg ridges are very close. In the velocity diagram, the location of Arabia and India plates leaves a wide range of possible rates and azimuths for the Ar-In vector (Figure 3a). Because of these uncertainties, the triple junction could have evolved as either ridge-fault-fault with a completely flat velocity triangle (Figure $3 b$ ) or ridge-ridge-ridge with an oblique-spreading ridge at the Arabia-India boundary (Figure 3c). In the following, we discuss the implications of our new data for the evolution of the triple junction over the past $8 \mathrm{~m} . \mathrm{y}$.

\section{Main morphological features of the eastern Sheba Ridge}

The axial rift of the eastern Sheba Ridge is underlined by shallow focus earthquakes (Figure 4). An important seismic swarm observed at $14.4^{\circ} \mathrm{N}$ and $56.6^{\circ} \mathrm{E}$ corresponds to a seismic crisis which occurred from April 19 to 24, 1975 (44 earthquakes; $4.5<\mathrm{m}_{\mathrm{b}}<5.3$ ), probably related to a dyke intrusion event, based on similarities with seismic swarms associated with dyke intrusions in Iceland (Einarsson, 1986; Sykes, 1970). Focal mechanisms of earthquakes along the axial rift $\left(4.9<\mathrm{m}_{\mathrm{b}}<5.8\right)$ are all of normal type (Harvard CMT; Dziewonski et al., 1981), with the exception of two off-axis compressional earthquakes at $13.3^{\circ} \mathrm{N}$, which occurred on November 22,2003 . On the multibeam map, the axial rift is sinuous and not segmented by transform faults. The Sheba Ridge deepens toward the 
southeast, where it connects to the Owen transform fault (OTF) through a deep nodal basin (6000 m) named the Wheatley Deep (Matthews et al., 1967).

The eastern Sheba Ridge can be divided into two segments exhibiting distinct morphologic and tectonic features (Figure 4). West of $57.2^{\circ} \mathrm{E}$, the western segment is characterized by a typical morphology of a slow-spreading ridge with a prominent $30-40 \mathrm{~km}$ wide median rift bounded by steeply-dipping normal faults stepping down toward the rift axis (Figures 4 and 5a). The axis of spreading is marked by a narrow zone of volcanic activity, which delineates a neovolcanic ridge (Figure 5a). Along this segment, the axial rift is relatively straight, shallow and continuous, with a $\mathrm{N} 120-130^{\circ} \mathrm{E}$ trend and depths between 3000 and $3800 \mathrm{~m}$. Linear escarpments corresponding to faults and dykes can be traced for long distances on both sides of the ridge axis. At $14^{\circ} \mathrm{N}$ and $57^{\circ} \mathrm{E}$, the rift axis is offset by a right-stepping, small offset $(\sim 10 \mathrm{~km})$ structure, corresponding to a non-transform discontinuity (Macdonald et al., 1988; Spencer et al., 1997; Van Wijk and Blackman, 2005).

East of $57.2^{\circ} \mathrm{E}$, the axial rift becomes more sinuous and deeper (between 4000 and $4500 \mathrm{~m}$ ). In this eastern area, the rift basin is bounded alternatively on its northern or southern sides by prominent domes bearing corrugations trending $\mathrm{N} 27^{\circ} \mathrm{E} \pm 3^{\circ}$, i.e., parallel to the direction of spreading (Figures 4 and $5 b$ ). These structures are interpreted as oceanic core complexes, also named mega-mullions, resulting from the exhumation of lower crustal or upper mantle rocks along low-angle normal faults rooting below the rift valley (Cann et al., 1997; Tucholke et al., 1998). This eastern part is segmented by a large non-transform discontinuity at $13.2^{\circ} \mathrm{N}$ and $57.5^{\circ} \mathrm{E}$ where the rift axis is offset by about $25 \mathrm{~km}$ (Figure 4).

The free-air gravity map was built using a Delaunay triangulation method (GMT software, Wessel and Smith, 1991) with an original data spacing of $\sim 30 \mathrm{~m}$ along the tracks and of $\sim 17 \mathrm{~km}$ between the tracks. The mantle Bouguer anomaly $\Delta m g$ was computed in the spectral domain using a Fast Fourier Transform algorithm provided by GMT with:

$$
\Delta m g(k)=2 \pi G\left[B(k)\left(\Delta \rho_{1} \mathrm{e}^{-k d}+\Delta \rho_{2} \mathrm{e}^{-k l}\right)\right]
$$

where $k$ is the wavenumber, $B$ is the topography variation (identical for the water/crust and crust/mantle interfaces), $\mathrm{G}$ is the gravitational constant, $\Delta \rho_{1}$ and $\Delta \rho_{2}$ are the density contrasts for the water/crust and crust/mantle interfaces (1840 and $300 \mathrm{~kg} . \mathrm{m}^{-3}$, respectively), and $d$ and $l$ are the mean depths of these interfaces (2500 and $7500 \mathrm{~m}$, respectively). The free-air gravity map displays relative highs following the Sheba Ridge topography (Figure 6). Two elevated peaks of more than $60 \mathrm{mGal}$ immediately north of the axial rift correspond to two large oceanic core complexes. A triangular area of negative mantle Bouguer anomaly covers the 
western part of the Sheba Ridge. On the other hand, positive values are encountered in the eastern part of the surveyed area, except at its northeastern extremity. To first order, mantle Bouguer anomaly variations may reflect crustal thickness variations: the relatively low anomaly found in the western part of the Sheba ridge, correlated with the high topography, could indicate a thick oceanic crust there, while the positive anomaly observed on the eastern part of the ridge could be associated with a reduced crustal thickness in the domain where core complex exhumation prevails.

\section{Formation of a rift basin at the southern end the OFZ}

In the northeastern part of the surveyed area, the southern extremity of the OFZ has been mapped over about $120 \mathrm{~km}$ (Figures 4 and 7). The OFZ appears as a rectilinear fault trending $\mathrm{N} 10^{\circ} \mathrm{E} \pm 3^{\circ}$ (Figure 7a). This vertical fault crosscuts the Owen topographic ridge and offsets it dextrally. The total displacement along the fault is estimated from a right-lateral apparent geomorphologic offset of $12 \pm 1 \mathrm{~km}$ measured on the multibeam map (Figure $7 \mathrm{~b}$ ). The fault does not display any noticeable vertical offset. It is a nearly pure strike-slip fault.

To the south, the OFZ forms the eastern margin of a $50 \mathrm{~km}$-wide basin bounded by $\mathrm{N} 70^{\circ} \mathrm{E}$ to $\mathrm{N} 90^{\circ} \mathrm{E}$ trending normal faults, and connects to the south with the southern border normal faults (Figures $7 \mathrm{~b}$ and 8 ). The basin thus consists of a transtensional pull-apart basin that is forming at the southern extremity of the OFZ. We would like to suggest the name of Beautemps-Beaupré Basin for this still unnamed feature. Seismicity in the basin and one extensional focal mechanism at the northern edge of the basin (Harvard CMT, September 12, $1990, \mathrm{~m}_{\mathrm{b}}=5.5$ ) attest of active normal faulting. The southward steeply dipping nodal plane of the focal mechanism likely corresponds to the bounding fault plane.

Sub-bottom $3.5 \mathrm{kHz}$ profiles reveal the shallow structure of the Beautemps-Beaupré Basin (Figure 9). In its eastern part, the basin is bounded to the north and the south by two major conjugate normal faults displaying a vertical geomorphologic offset of about $100 \mathrm{~m}$ (profile AOC3). This offset progressively decreases westward and vanishes in the western part of the basin (Figures $7 \mathrm{~b}$ and 9). Inside the basin, numerous minor normal faults with offsets smaller than $10 \mathrm{~m}$ crosscut the youngest sedimentary deposits (Figure 9). Some of them display a downward increasing offset, which attests of their synsedimentary activity (see blow-up of profile AOC3 in Figure 9). On the $3.5 \mathrm{kHz}$ profiles, the basin infill is characterized from top to bottom by a layered seismic sequence with strong reflections overlying two thick transparent layers (tr1 and tr2 in profiles AOC5 and AOC6). The layered sequence may represent turbidites, as multibeam data show that the Beautemps-Beaupré 
Basin is supplied in turbidity-current deposits by a channel coming from the Indus Fan. The upper transparent layer ( $\operatorname{tr} 2)$ can be correlated from west to east from profile AOC6 to AOC3, whereas the lower one $(\operatorname{tr} 1)$ is observed only on profiles AOC5 and AOC6. This observation indicates that sedimentary sequences become thicker from west to east, reflecting an eastward increase of the subsidence rate. The eastern part of the basin is asymmetrical with a larger cumulative normal fault offset in its southern half, at the location of the present-day depocentre (profile AOC3). On the other hand, in its western part, the basin is divided into two sub-basins separated by a central horst, and numerous normal faults are observed on the southern edge of the basin (profile AOC5).

The eastern part of the Beautemps-Beaupré basin is characterized by a strong negative free-air gravity anomaly of $\sim 100 \mathrm{mGal}$ with respect to the surrounding crust, probably due to a thick low-density sedimentary infill (Figures 6 and profiles 2 and 3 in Figure 10). Moreover, the gravity minimum is offset southwards by about $5 \mathrm{~km}$ with respect to the basin centre, suggesting an asymmetrical infill with a greater basement depth to the south, in agreement with the high density of normal faults there. The gravity low in the western part of the basin is about half that of the eastern basin (profiles 5 and 6 in Figure 10), suggesting a less well developed basin there in agreement with the westward decreasing subsidence observed on $3.5 \mathrm{kHz}$ profiles. This part of the basin has probably recently developed within the oceanic crust of the northern flank of the Sheba Ridge. In contrast to the sharp eastern border of the basin that forms the active OFZ, its western edge is poorly defined and is marked by numerous landslides on the surrounding oceanic highs (Figure 8 and profile AOC6). Southwest of the basin, the oceanic crust is cut by E-W trending faults offsetting former structures (dykes and faults) formed at the Sheba Ridge. The extensional deformation thus seems to propagate westward into the oceanic crust, its style evolving from localized to diffuse from east to west. Two large earthquakes with strike-slip focal mechanisms occurred in the area (Figures 4 and 8; Harvard CMT, December 5, 1981, $\mathrm{m}_{\mathrm{b}}=5.6$; December 14, 1985, $\left.\mathrm{m}_{\mathrm{b}}=5.5\right)$, but the corresponding fault planes could not be clearly identified on the multibeam map.

In summary, this new set of marine data shows that the southern part of the active OFZ corresponds to a pure right-lateral active fault with a visible finite offset of $12 \mathrm{~km}$. Motion along this fault postdates the uplift of the Owen Ridge. The onset of motion along the fault, obtained by dividing its finite offset by the mean rate of motion, has been estimated between 4 and $8 \mathrm{Ma}$ (Fournier et al., 2008). The fault terminates into an active rift basin some $250 \mathrm{~km}$ north of the Sheba Ridge. The basin probably started to develop 4 to $8 \mathrm{Ma}$ ago 
together with the active fault. The extensional deformation appears to propagate westward into the oceanic crust, but does not presently join the axial rift of the Sheba Ridge. The AOC triple junction presently corresponds to a widespread zone of distributed deformation.

\section{Submarine landslides along the active OFZ}

The Owen Ridge is a prominent topographic ridge of $2000 \mathrm{~m}$ height with respect to the surrounding seafloor. Seismic profiles indicate that the ridge is asymmetric with a steep east-facing scarp associated with the Owen fracture zone and a gentle western slope corresponding to sedimentary beds tilted a few degrees toward the west (Whitmarsh et al., 1974; Mountain and Prell, 1990). On the western slope, seismic profiles acquired during the DSDP Leg 23 showed that the uppermost sediments have been stripped off without disturbing underlying reflectors, presumably by sliding of non-competent beds over more competent beds. The scarps produced at the point of detachment of the upper layers have been observed on seismic profiles (Whitmarsh et al., 1974). Our multibeam data also reveal several sinuous headwall scars of landslide on the western slope of the Owen Ridge (Figure 7b). After failure on the slope, these landslides must have generated typical slope deposits such as debrites (the deposit formed by a debris flow) and turbidites. On the northern margin of the BeautempsBeaupré Basin, the thick lens-shaped sediment bodies displaying a transparent seismic facies on $3.5 \mathrm{kHz}$ profiles (profiles AOC2 and AOC5 in Figure 9) may correspond to debrites, by analogy with similar deposits unequivocally identified as debrites by coring (Lastras et al., 2004; Talling et al., 2007). On the AOC5 profile, three superimposed transparent bodies separated by thin layered-sequences attest of frequent landslides on the Owen Ridge. The largest debris-flow deposit, which is also laterally observed on profile AOC2, is about $30 \mathrm{~m}$ thick (assuming a mean sound speed of $1800 \mathrm{~m} \mathrm{~s}^{-1}$ ). The fine-grained portion of the debris flow might have been deposited further south in the deep basin and could correspond to the thick transparent layers ( $\operatorname{tr} 1$ and $\operatorname{tr} 2)$ observed on the $3.5 \mathrm{kHz}$ profiles. Giant landslides along the Owen Ridge are probably triggered by earthquakes occurring along the OFZ or along the normal faults of the basin.

\section{Discussion: development of an ultra-slow divergent plate boundary}

\subsection{Rift nucleation at the ocean-ocean transition (OOT)}

At the southern end of the OFZ, rifting localises at the transition zone between the recent oceanic crust created at the Sheba Ridge and a crust of different origin pertaining to the Owen basin (Figure 2). The latter, located between the OFZ and the Arabian continental 
margin (Oman margin), is mainly floored with oceanic crust as indicated by seismic reflection and refraction data (Whitmarsh, 1979; Stein and Cochran, 1985; Barton et al., 1990). Its age remains poorly constrained however because it lacks clearly identified sequences of lineated magnetic anomalies. It could correspond to the ancient passive margin of the Africa-Arabia continent formed during the break-up of Gondwanaland (Whitmarsh, 1979; Stein and Cochran, 1985). In this case, the crust would be of Late Jurassic-Early Cretaceous age like the North Somali Basin (Bunce et al., 1967; Cochran, 1988) and like the ophiolites emplaced on the Oman margin in Masirah Island and Ra's Madrakah (Figure 2; Beurrier, 1987; Smewing et al., 1991; Peters and Mercolli, 1998). However, the unloaded basement depth in the Owen basin is more than $1 \mathrm{~km}$ shallower than expected for an oceanic crust of Jurassic age (Mountain and Prell, 1990). Moreover, correlation of seismic profiles with the DSDP 224 drilling rather supports a Late Cretaceous or younger age for the basement of the Owen basin (see Edwards et al., 2000 for a synthesis). Whatever its age, this ancient oceanic lithosphere was rifted apart in the Early Miocene to form the easternmost segment of the Sheba Ridge between the eastern edges of Arabia and Africa to the OFZ. The newly formed BeautempsBeaupré rift basin nucleated at the transition zone between the old oceanic lithosphere of the Owen Basin and the Miocene oceanic lithosphere of the Sheba Ridge, i.e., in the ocean-ocean transition (OOT) zone, by analogy with the ocean-continent transition (OCT) at the foot of the rifted continental margin of the Gulf of Aden (d'Acremont et al., 2005; see also Shillington et al., 2006). In the eastern Gulf of Aden, the OOT nearly coincides with the "magnetic quiet zone" described by Cochran $(1981,1982)$. The OOT appears as a zone of rheological weakness where intra-oceanic rifting was initiated some 4-8 Ma ago, before propagating westward in the oceanic lithosphere of the northern Sheba Ridge.

\subsection{Is the present-day AOC triple junction stable or transient?}

On the multibeam map (Figure 4), there is no evidence of active deformation along the seismically quiet segment of the OFZ between $12.8^{\circ} \mathrm{N}$ and $15^{\circ} \mathrm{N}$, which separates the oceanic lithosphere formed at the Sheba Ridge to the west from that formed at the Carlsberg Ridge to the east. The Arabia-India plate boundary terminates into the Beautemps-Beaupré rift basin some $250 \mathrm{~km}$ north of the Sheba Ridge and it is diffuse and not marked by a well-defined seismic zone between the BB Basin and the ridge axis (Figure 11b).

Before the initiation of the new plate boundary fault (i.e., 4-8 Ma ago), the southern segment of the OFZ between $12.8^{\circ} \mathrm{N}$ and $15^{\circ} \mathrm{N}$ was probably active and accommodated the Arabia-India dextral relative motion inferred from magnetic data from the Sheba and 
Carlsberg ridges (Gordon and DeMets, 1989). The AOC triple junction was then located at the junction of the old OFZ, the Sheba Ridge, and the OTF with a ridge-fault-fault (RFF) geometry (Figure 11a). Since this kind of triple junction is often unstable, it was probably abandoned when a change of the Arabia-India kinematics caused the activation of the newly imaged fault together with the formation of the Beautemps-Beaupré Basin. The latest kinematic reorganization in the Indian Ocean occurred $\sim 8 \mathrm{Ma}$ ago and corresponds to the onset of intraplate deformation in the India-Australia plate dated at 7.5-8 Ma by ODP drillings (Cochran, 1990; Chamot-Rooke et al., 1993; Delescluse and Chamot-Rooke, 2007), which nearly coincides with kinematic change along the Carlsberg Ridge between 11 and $9 \mathrm{Ma}$ (Merkouriev and DeMets, 2006).

The Beautemps-Beaupré rift basin was initiated at the OOT and propagated westward into the Arabian plate interior. An ultraslow divergent boundary is therefore developing between Arabia and India and might join the Sheba Ridge axis in the future to reach a more stable ridge-ridge-ridge triple junction (Figure 11c). Part of the Arabian plate is thus being transferred to the Indian plate (DeMets, 2008). At present, deformation is not clearly localised between the $\mathrm{BB}$ Basin and the Sheba Ridge, and the current configuration of the triple junction appears as a transient state preceding the establishment of a new divergent plate boundary.

\subsection{Future evolution of the AOC triple junction}

As shown in Figure 1, the geometry of the AOC triple junction is the same as that of the Azores triple junction rotated counterclockwise by $90^{\circ}$. Moreover, the Africa-Iberia-North America triple junction that existed when Iberia was moving independently from Eurasia at the time of opening of King's Trough, from 44 to $25 \mathrm{Ma}$, also had a similar geometry with an oblique rift - King's Trough - connecting a transform fault to the MAR (Srivastava et al., 1990). This geometry thus seems to be common in a context of connection of a transform fault with a spreading ridge. Another similarity between the AOC and Azores triple junctions is their plate velocity-space diagrams with two slow-spreading ridges having similar rates and directions, and one ultra-slow spreading boundary forming the third arm (Searle, 1980). The main difference between the two triple junctions is the existence of a hot spot beneath the Azores triple junction. The Azores triple junction, with its well-developed Terceira rift, might represent a future stage of development of the AOC triple junction. Then, the rift arm of the Azores and AOC triple junctions could evolve into an oceanic spreading center, like for Juan 
Fernandez triple junction where a spreading ridge developed at the termination of the Chile Transform.

\section{Conclusion}

Do RRF (or RFF) triple junctions really exist on Earth? Amongst the three known active examples of such triple junctions, previous studies have demonstrated that two of them are actually of the RRR type. Our study shows that the last one - the AOC triple junction in the Indian Ocean - is also evolving into a RRR-type junction. As a consequence, despite the fact that the regional plate configuration and far-field kinematics may define a RRF or RFF connection, the local geometry of the triple junction is always of RRR type. The substitution of RRF (or RFF) triple junctions by more stable RRR triple junctions with a rift arm may be a mechanical adaptation of the oceanic lithosphere to changing kinematic boundary conditions.

Acknowledgements. We thank Neil Mitchell and Tim Minshull for their detailed and constructive reviews, and Basin Research Associate Editor Frederik Tillmann for numerous corrections. We benefited from fruitful discussions with Philippe Patriat and Sunseare Gabalda. We are indebted to the Captain Alain Le Bail, officers, and crew members of the BHO Beautemps-Beaupré, and to the French Navy Hydrographer Simon Blin and his hydrographic team of the 'Mission Océanographique de l'Atlantique', for their assistance in data acquisition. We acknowledge the support of SHOM and IFREMER for the AOC cruise. Figures were drafted using GMT software (Wessel and Smith, 1991). In French, A.O.C. is an acronym for "Appellation d'Origine Contrôlée”, a label used for food products, such as wines or cheeses, coming from a geographically defined and limited area ("terroir"). AOC sounds like an appropriate name for a triple junction close to the Carlsberg Ridge. 


\section{References}

Argus D.F., Gordon R.G., DeMets C. \& Stein S. (1989) Closure of the Africa-North America plate motion circuit and tectonics of the Gloria fault, J. Geophys. Res., 94, 5585-5602.

Barton, P. J., Owen, T. R. E. \& White, R. S. (1990) The deep structure of the east Oman continental margin: preliminary results and interpretation, Tectonophys., 173, 319-331.

Bellahsen, N., Fournier, M., d'Acremont, E., Leroy, S. \& Daniel J.-M. (2006) Fault reactivation and rift localization: The northeastern Gulf of Aden margin, Tectonics, 25, doi: 10.1029/2004TC001626.

Beurrier, M. (1987) Géologie de la nappe ophiolitique de Semail dans les parties orientales et centrales de l'Oman, Thèse Doc. Etat, Univ. Paris 6, 406 pp.

Bird, R.T. \& Naar, D.F. (1994) Intratransform origins of midocean ridge microplates, Geology, 22, 987-990.

Bird, R.T., Naar, D.F., Larson, R.L., Searle, R. C. \& Scotese, C. R. (1998) Plate tectonic reconstructions of the Juan Fernandez microplate: Transformation from internal shear to rigid rotation, J. Geophys. Res., 103, 7049-7067.

Briais, A., Aslanian, D., Géli, L. \& Ondréas, H. (2002) Analysis of propagators along the Pacific-Antarctic Ridge: evidence for triggering by kinematic changes, Earth planet. Sci. Lett., 199, 415-428.

Bunce, E. T., Langseth, M. G., Chase, R. L. \& Ewing, M. (1967) Structure of the Western Somali Basin, J. Geophys. Res., 72, 2547-2555.

Cann, J.R., Blackman, D.K., Smith, D.K., McAllister, E., Janssen, B., Mello, S., Avgerinos, E., Pascoe, A.R. \& Escartin, J. (1997) Corrugated slip surfaces formed at ridge-transform intersections on the Mid-Atlantic Ridge, Nature, 385, 329-332.

Cannat, M., Sauter, D., Mendel, V., Ruellan, E., Okino, K., Escartin, J., Combier, V. \& Baala, M. (2006) Modes of sea floor generation at a melt-poor ultraslow-spreading ridge, Geology, 34, 605-608. 
Chaubey, A.K, Dyment, J., Bhattacharya, G.C., Royer, J.-Y., Srinivas, K. \& Yatheesh, V. (2002) Paleogene magnetic isochrons and paleo-propagators in the Arabian and Eastern Somali basins, Northwest Indian Ocean. In: P. Clift, D. Kroon, C. Gaedicke and J. Craig (eds), The Tectonic \& Climatic Evolution of the Arabian Sea Region. Geological Society Special Publication, 195, 71-85.

Chamot-Rooke, N., Jestin, F., De Voogd, B. \& the Phèdre Working Group (1993) Intraplate shortening in the central Indian Ocean determined from 2100-km-long north-south deep seismic re ection pro le, Geology, 21, 1043-1046.

Cochran, J.R. (1981) The Gulf of Aden: structure and evolution of a young ocean basin and continental margin, J. Geophys. Res., 86, 263-287.

Cochran, J.R. (1982) The magnetic quiet zone in the eastern of the Gulf of Aden: implications for the early development of the continental margin, Geophys. J. Royal Astron. Soc., 68, 171-201.

Cochran, J.R. (1988) Somali Basin, Chain Ridge, and origin of the Northern Somali Basin gravity and geoid low, J. Geophys. Res., 93, 11,985-12,008.

Cochran, J.R. (1990) Himalayan uplift, sea level, and the record of Bengal Fan sedimentation at the ODP LEG 116 Sites, Proceedings of the Ocean Drilling Program, Scientific Results, 116, 397-414.

d'Acremont, E., Leroy, S., Beslier, M.-O., Bellahsen, N., Fournier, M., Robin, C., Maia, M. \& Gente, P. (2005) Structure and evolution of the eastern Gulf of Aden conjugate margins from seismic reflection data, Geophys. J. Int., 160, 869-890.

d'Acremont, E., Leroy, S., Maia, M., Patriat, P., Beslier, M.-O., Bellahsen, N., Fournier, M. \& Gente, P. (2006) Structure and evolution of the eastern Gulf of Aden: insigths from magnetic and gravity data (Encens Sheba Cruise), Geophys. J. Int., 165, 786-803. 
Delescluse, M. \& Chamot-Rooke, N. (2007) Instantaneous deformation and kinematics of the India-Australia Plate, Geophys. J. Int., 168, 818-842.

DeMets, C. (2008) Arabia's slow danse with India. Nature Geoscience, 1, 10-11, doi:10.1038/ngeo.2007.56

DeMets, C., Gordon, R.G., Argus, D.F. \& Stein, S. (1990) Current plate motions, Geophys. J. Int., 101, 425-478.

DeMets, C., Gordon, R.G., Argus, D.F. \& Stein, S. (1994) Effect of recent revisions of the geomagnetic reversal time scale on estimates of current plate motions, Geophys. Res. Lett. 21, 2191-2194.

Dyment, J. (1993) Evolution of the Indian Ocean triple junction between 65 and $49 \mathrm{Ma}$ (Anomalies 28 to 21), J. Geophys. Res., 98, 13863-13877.

Dziewonski, A. M., Chou, T. A. \& Woodhouse, J. H. (1981) Determination of earthquake source parameters from waveform data for studies of global and regional seismicity, $J$. Geophys. Res., 86, 2825-2852.

Edwards, R. A., Minshull T. \& White, R. S. (2000) Extension across the Indian-Arabian plate boundary: the Murray Ridge, Geophys. J. Int., 142, 461-477.

Einarsson, P. (1986) Seismicity along the eastern margin of the North American plate, in The Geology of North America: Vol. M, The Western North Atlantic Region, edited by P.R. Vogt, and B.E. Tucholke, pp. 99-116, The Geological Society of America, Boulder, CO.

Ellouz-Zimmermann, N., Lallemant, S., Castilla, R., Mouchot, N., Leturmy, P., Battani, A., Buret, C., Cherel, L., Desaubliaux, G., Deville, E., Ferrand, J., Luqcke, A., Mahieux, G., Mascle, G., Muhr, P., Pierson-Wickmann, A., Robion, P., Schmitz, J., Danish, M., Hasanv, S., Shahzad, A., \& Tabreez, A. (2007) Offshore frontal part of the Makran Accretionary prism: The Chamak survey (Pakistan). In: Lacombe, O., Lavé, J., Roure, F., Vergés, J. 
(Eds.). Thrust Belts and Foreland Basins - From Fold Kinematics to Hydrocarbon System, Frontiers in Earth Science Series, Springer Berlin Heidelberg, 351-366.

Engdahl, E.R., van der Hilst, R. \& Buland, R. (1998) Global teleseismic earthquake relocation with improved travel times and procedures for depth determination, Bull. Seismol. Soc. Am., 88, 722-743.

Falconer, R.K.H. (1972) The Indian-Antarctic-Pacific Triple Junction, Earth and Planetary Science Letters, 17, 151-158.

Fernandes, R.M.S., Bastos, L., Miranda, J.M., Lourenço, N., Ambrosius, B.A.C., Noomen, R. \& Simons, W. (2006) Defining the plate boundaries in the Azores region, J. Volc. Geotherm. Res., 156, 1-9.

Fournier, M., Bellahsen, N., Fabbri, O. \& Gunnell, Y. (2004) Oblique rifting and segmentation of the NE Gulf of Aden passive margin, Geochemistry Geophysics Geosystems, 5, Q11005, doi:10.1029/2004GC000731.

Fournier, M., Chamot-Rooke, N., Petit, C., Fabbri, O., Huchon, P., Maillot, B. \& Lepvrier, C. (2008) In-situ evidence for dextral active motion at the Arabia-India plate boundary, Nature Geoscience, 1, 54-58, doi:10.1038/ngeo.2007.24.

Fournier, M., Huchon, P., Khanbari, K. \& Leroy, S. (2007) Segmentation and along-strike asymmetry of the passive margin in Socotra, eastern Gulf of Aden: Are they controlled by detachment faults?, Geochemistry Geophysics Geosystems, 8, Q03007, doi:10.1029/2006gc001526.

Fournier, M., Lepvrier, C., Razin, P. \& Jolivet, L. (2006) Late Cretaceous to Paleogene postobduction extension and subsequent Neogene compression in the Oman Mountains, GeoArabia, 11, 17-40

Fournier, M., Patriat, P. \& Leroy, S. (2001) Reappraisal of the Arabia-India-Somalia triple junction kinematics, Earth Planet. Sci. Lett., 189, 103-114. 
Gaedicke, G., Prexl, A., Schlüter, H.-U., Meyer, H., Roeser, H. A. \& Clift, P. (2002a) Seismic stratigraphy and correlation of major regional unconformities in the northern Arabian Sea, Geol. Soc. London Spec. Pub., 195, 25-36.

Gaedicke, G., Schlüter, H.-U., Roeser, H. A., Prexl, A., Schreckenberger, B., Meyer, H., Reichert, C., Clift, P. \& Amjad, S. (2002b) Origin of the northern Indus Fan and Murray Ridge, Northern Arabian Sea: interpretation from seismic and magnetic imaging, Tectonophysics, 355, 127-143.

Gordon, R.G. \& DeMets, C. (1989) Present-day motion along the Owen fracture zone and Dalrymple trough in the Arabian Sea, J. Geophys. Res., 94, 5560-5570.

Gunnell, Y., Carter , A., Petit , C. \& Fournier M. (2007) Post-rift seaward downwarping at passive margins: new insights from southern Oman using stratigraphy to constrain apatite fission-track and (U-Th)/He dating, Geology, 35, 647-650, doi:10.1130/G23639A.1

Hey, R.N. (1977) A new class of pseudofaults and their bearing on plate tectonics: A propagating rift model, Earth Planet. Sci. Lett., 37, 321-325.

Honsho, C., Tamaki, K. \& Fujimoto, H. (1996) Three-Dimensional Magnetic and Gravity Studies of the Rodriguez Triple Junction in the Indian Ocean, J. Geophys. Res., 101, $15837-15848$.

Huchon, P. \& Khanbari, K. (2003) Rotation of the syn-rift stress field of the northern Gulf of Aden margin, Yemen, Tectonophysics, 364, 147-166.

Ildefonse, B., Blackman, D.K., John, B.E., Ohara, Y., Miller, D. J., MacLeod, C. J. \& Integrated Ocean Drilling Program Expeditions 304/305 Science Party (2007) Oceanic core complexes and crustal accretion at slow-spreading ridges, Geology, 35, 623-626, doi: 10.1130/G23531A.1.

Jestin, F., Huchon, P. \& Gaulier, J.M. (1994) The Somalia plate and the East African rift system: Present-day kinematics, Geophys. J. Int., 116, 637-654. 
Klein, E.M., Smith, D.K., Williams, C.M. \& Schouten, H., (2005) Counter-rotating microplates at the Galapagos triple junction, Nature, 433, 855-858.

Kleinrock, M.C. \& Hey, R.N. (1989) Detailed tectonics near the tip of the Galapagos $95.5^{\circ} \mathrm{W}$ propagator: How the lithosphere tears and a spreading axis develops, J. Geophys. Res., 94, 13801-13838.

Kreemer, C., Holt, W.E. \& Haines, A.J. (2003) An integrated global model of present-day plate motions and plate boundary deformation, Geophys. J. Int., 154, 8-34.

Kruse, S.E., Tebbens, S.F., Naar, D.F., Lou, Q. \& Bird, R.T. (2000) Comparisons of gravity anomalies at pseudofaults, fracture zones, and nontransform discontinuities from fast to slow spreading areas, J. Geophys. Res., 105, 28399-28410.

Lafoy, Y., Auzende, J.M., Ruellan, E., Huchon, P. \& Honza, E. (1990) The 16²0'S triple junction in the North Fiji Basin (SW Pacific), Mar. Geophys. Res., 12, 285-296.

Larson, R.L., Searle, R.C., Kleinrock, M.C., Schouten, H., Bird, R.T., Naar, D.F., Rusby, R.I., Hooft, E.E. \& Lasthiotakis, H. (1992) Roller-bearing tectonic evolution of the Juan Fernandez microplate, Nature, 356, 571-576.

Laughton, A.S, Whitmarsh, R.B. \& Jones, M.T. (1970) The evolution of the Gulf of Aden, Philos. Trans. R. Soc. London, A267, 227-266.

Lepvrier, C., Fournier, M., Bérard, T. \& Roger, J. (2002) Cenozoic extension in coastal Dhofar (southern Oman): Implications on the oblique rifting of the Gulf of Aden, Tectonophysics, 357, 279-293.

Leroy, S., Gente, P., Fournier, M., d'Acremont, E., Bellahsen, N., Beslier, M.-O., Patriat, P., Maia, M., Blais, A., Perrot, J., Al-Kathiri, A., Merkouriev, S., Ruellan, P.-Y., Fleury, J.M., Lepvrier, C. \& Huchon, P. (2004) From rifting to spreading in the eastern Gulf of Aden: a geophysical survey of a young oceanic basin from margin to margin, Terra Nova, 16, $185-192$. 
Ligi, M., Bonatti, E., Bortoluzzi, G., Carrara, G., Fabretti, P., Penitenti, D., Gilod, D., Peyve, A.A., Skolotnev, S. \& Turko, N. (1997) Death and transfiguration of a triple junction in the South Atlantic, Science, 276, 243-245.

Ligi, M., Bonatti, E., Bortoluzzi, G., Carrara, G., Fabretti, P., Gilod, D., Peyve, A.A., Skolotnev, S. \& Turko, N. (1999) Bouvet triple junction in the South Atlantic: Geology and evolution, J. Geophys. Res., 104, 29365-29385.

Lonsdale, P. (1988) Structural pattern of the Galapagos microplate and evolution of the Galapagos triple junction, J. Geophys. Res., 93, 13551-13574.

Luis, J. F., Miranda, J.M., Galdeano, A., Patriat, P., Rossignol, J.C. \& Mendes Victor, L.A. (1994) The Azores triple junction evolution since 10 Ma from an aeromagnetic survey of the Mid-Atlantic Ridge, Earth Planet. Sci. Lett., 125, 439-459.

Macdonald, K. C., Fox, P. J., Perram, L. J., Eisen, M. F., Haymon, R. M., Miller, S. P., Carbotte, S. M., Cormier, M. H. \& Shor, A. N. (1988) A new view of the mid-ocean ridge from the behaviour of ridge axis discontinuities, Nature, 335, 217-225.

Matthews, D. H. (1966) The Owen fracture zone and the northern end of the Carlsberg Ridge. Phil. Trans. Royal Soc., A, 259, 172-186.

Matthews, D. H., Williams, C. \& Laughton, A. S. (1967) Mid-ocean ridge in the mouth of the Gulf of Aden, Nature, 215, 1052-1053.

McKenzie, D. P. \& Sclater, J. G. (1971) The evolution of the Indian Ocean since the Late Cretaceous, Geophys. J. Roy. Astron. Soc., 25, 437-528.

McKenzie, D.P. \& Morgan, W.J. (1969) Evolution of triple junctions, Nature, 224, 125-133.

Mercuriev, S., Patriat, P. \& Sochevanova, N. (1996) Evolution de la dorsale de Carlsberg: évidence pour une phase d'expansion très lente entre 40 et $25 \mathrm{Ma}$ (A18 à A7), Oceanologica Acta, 19, 1-13. 
Merkouriev, S. \& DeMets, C. (2006) Constraints on Indian plate motion since $20 \mathrm{Ma}$ from dense Russian magnetic data: Implications for Indian plate dynamics, Geochem. Geophys. Geosyst., 7, Q02002, doi:10.1029/2005GC001079.

Minshull, T. A., White, R. S., Barton, P. J. \& Collier, J. S. (1992) Deformation at plate boundaries around the Gulf of Oman, Marine Geology, 104, 265-277.

Mitchell, N.C. \& Livermore, R.A. (1998) The present configuration of the Bouvet triple junction, Geology, 26, 267-270.

Mitchell, N.C. \& Parson, L.M. (1993) The tectonic evolution of the Indian Ocean Triple Junction, Anomaly 6 to Present, J. Geophys. Res., 98, 1793-1812.

Mitchell, N.C. (1991) Distributed extension at the Indian Ocean Triple Junction, J. Geophys. Res., 96, 8019-8043.

Mitchell, N.C., Livermore, R.A., Fabretti, P. \& Carrara, G. (2000) The Bouvet Triple Junction, 20 to $10 \mathrm{Ma}$, and Extensive Transtensional deformation adjacent to the Bouvet and Conrad transforms, J. Geophys. Res., 105, 8279-8296.

Mountain, G. S. \& Prell, W. L. (1990) A multiphase plate tectonic history of the southeast continental margin of Oman, In: Robertson, A. H. F., Searle, M. P. and Ries, A. C. (eds) the Geology and Tectonics of the Oman Region, Geol. Soc. London Spec. Pub., 49, 725743.

Munschy, , M. \& Schlich, R. (1989) The Rodriguez triple junction (Indian Ocean) - Structure and evolution for the past one million years, Mar. Geophys. Res., 11, 1-14.

Nocquet, J.-M., Willis, P. \& Garcia, S. (2006) Plate kinematics of Nubia-Somalia using a combined DORIS and GPS solution, J. Geodesy, 80, 591-607.

Norton, I.O. \& Sclater, J. G. (1979) A model for the evolution of the Indian Ocean and the breakup of the Gondwanaland, J. Geophys. Res., 84, 6803-6830 
Ohara, Y., Yoshida, T., Kato, Y. \& Kasuga, S. (2001) Giant megamullion in the Parece Vela backarc basin, Marine Geophysical Research, 22, 47-61.

Patriat P. \& Courtillot, V. (1984) On the stability of triple junctions and its relation to episodicity in spreading, Tectonics, $\mathbf{3}, 317-332$.

Patriat P. \& Parson, L. (1989) A survey of the Indian Ocean Triple Junction trace within the Antarctic plate: Implications for the junction evolution since $15 \mathrm{Ma}$, Marine Geophysical Research, 11, 89-100.

Peters, T. \& Mercolli, I. (1998) Extremely thin oceanic crust in the Proto-Indian Ocean: Evidence from the Masirah Ophiolite, Sultanate of Oman, J. Geophys. Res., 103, 677-689.

Petit, C., Fournier, M. \& Gunnell, Y. (2007) Tectonic and climatic controls on rift escarpments: Erosion and flexural rebound of the Dhofar passive margin (Gulf of Aden, Oman), $J$. Geophys. Res., 112, B03406, doi:10.1029/2006JB004554

Quittmeyer, R.C. \& Kafka, A.L. (1984) Constraints on plate motions in southern Pakistan and the northern Arabian Sea from the focal mechanisms of small earthquakes, J. Geophys. Res., 89, 2444-2458.

Reilinger R. et al. (2006) GPS constraints on continental deformation in the Africa-ArabiaEurasia continental collision zone and implications for the dynamics of plate interactions, J. Geophys. Res., 111, B05411, doi:10.1029/2005JB004051.

Royer, J.-Y., Chaubey, A. K., Dyment, J., Bhattacharya, G. C., Srinivas, K., Yatheesh, V., \& Ramprasad, T. (2002) Paleogene plate tectonic evolution of the Arabian and Eastern Somali basins. In: The Tectonic \& Climatic Evolution of the Arabian Sea Region (Ed. by P. Clift, D. Kroon, C. Gaedicke and J. Craig), Geological Society Special Publication, 195, 723.

Sahota, G. (1990) Geophysical investigations of the Gulf of Aden Continental Margins: Geodynamic implications for the Development of the Afro-Arabian Rift System, Ph.D. Thesis: Swansea, University College. 
Schmidt, J. (1932) Dana's Togt Omkring Jorden, 1928-1930, Gyldendal edn., Copenhagen, 269 pp.

Sclater, J. G., Bowin, C., Hey, R., Hoskins, H., Peirce, J., Phillips, J. \& Tapscott, C. (1976) The Bouvet triple junction, J. Geophys. Res., 81, 1857-1869.

Searle, R. (1980) Tectonic pattern of the Azores spreading center and triple junction, Earth Planet. Sci. Lett., 51, 415-434.

Searle, R., Cannat, M., Fujioka, K., Mével, C., Fujimoto, H., Bralee, A. \& Parson, L. (2003) Fuji Dome: A large detachment fault near $64^{\circ} \mathrm{E}$ on the very slow-spreading southwest Indian Ridge, Geochemistry, Geophysics, Geosystems, 4, 9105, doi: $2003 \mathrm{GC000519}$

Sella, G.F., Dixon, T.H. \& Mao, A.L. (2002) REVEL: A model for Recent plate velocities from space geodesy, J. Geophys. Res., 104, doi:10.1029/2000JB000033

Shillington D. J., Holbrook, W. S., Van Avendonk, H. J. A., Tucholke, B. E., Hopper, J. R., Louden, K. E., Larsen, H. C. \& Nunes G. T. (2006) Evidence for asymmetric nonvolcanic rifting and slow incipient oceanic accretion from seismic reflection data on the Newfoundland margin, J. Geophys. Res., 111, B09402, doi:10.1029/2005JB003981.

Smewing, J.D., Abbotts, I. L., Dunne, L.A. \& Rex, D.C. (1991) Formation and emplacement ages of the Masirah ophiolite, Sultanate of Oman, Geology, 19, 453-456.

Spencer, S., Smith, D. K., Cann, J. R., Lin, J. \& McAllister E. (1997) Structure and stability of non-transform discontinuities on the Mid-Atlantic Ridge betw een $24^{\circ} \mathrm{N}$ and $30^{\circ} \mathrm{N}$, Marine Geophysical Research, 19, 339-362.

Srivastava, S.P., Schouten, H., Roest, W. R., Klitgord, K. D., Kovacs, L. C., Verhoef, J. \& Macnab, R. (1990) Iberian plate kinematics: a jumping plate boundary between Eurasia and Africa, Nature, 344, 756-759.

Stein, C.A. \& Cochran, J.R. (1985) The transition between the Sheba ridge and the Owen basin: rifting of old oceanic lithosphere, Geophys. J. R. astr. Soc., 81, 47-74. 
Sykes, L. R. (1968) Seismological evidence for transform faults, sea floor spreading, and continental drift, History of the Earth's crust, A symposium, R. A. Phinney editor, 120-150.

Sykes, L. R. (1970) Earthquake swarms and sea-floor spreading, J. Geophys. Res., 75, 65986611.

Tapscott, C.R., Patriat, P., Fisher, R.L., Sclater, J.G., Hoskins, H. \& Parsons, B. (1980) The Indian Ocean Triple Junction, J. Geophys. Res., 85, 4723-4739.

Tiberi, C., Leroy, S., d'Acremont, E., Bellahsen, N., Ebinger, C., Al-Lazki, A. \& Pointu, A. (2007) Crustal geometry of the northeastern Gulf of Aden passive margin: localization of the deformation inferred from receiver function analysis, Geophys. J. Int., 168, 1247-1260.

Tucholke, B. E., Lin, J. \& Kleinrock M. C. (1998) Megamullions and mullion structure defining oceanic metamorphic core complexes on the Mid-Atlantic Ridge, J. Geophys. Res., 103, 9857-9866.

van Wijk, J.W. \& Blackman, D.K. (2005) Deformation of oceanic lithosphere near slowspreading ridge discontinuities, Tectonophysics, 407, 221-225.

Vigny, C., Huchon, P., Ruegg, J.C., Khanbari, K. \& Asfaw, L.M. (2006) Confirmation of Arabia plate slow motion by new GPS data in Yemen, J. Geophys. Res., 111, B02402, doi:10.1029/2004JB003229

Vogt, P.R. \& Jung, W.Y. (2004) The Terceira Rift as hyper-slow, hotspot-dominated oblique spreading axis: a comparison with other slow-spreading plate boundaries, Earth Planet. Sci. Lett., 218, 77-90.

Wessel, P., W. \& Smith, M. F. (1991) Free software helps map and display data, EOS Trans. $A G U, \mathbf{7 2}, 441-446$.

Whitmarsh, R.B. (1979) The Owen Basin off the south-east margin of Arabia and the evolution of the Owen Fracture Zone, Geophys. J. Royal Astron. Soc., 58, 441-470. 
Whitmarsh, R.B., Weser, O. E., Ross, D. A. \& al. (1974) Initial report DSDP, U.S. Government Printing Office, Washington, D.C., v. 23, p. 1180.

Wilson, T. J. (1965) A new class of faults and their bearing on continental drift, Nature, 207, $343-347$. 


\section{Figure captions}

Figure 1. Location of the three active examples of connection of a transform fault with two spreading ridges on Earth: the Gloria Fault (GF) with the Mid-Atlantic Ridge (MAR) at the Azores triple junction, the Chile Transform (ChT) with the East Pacific Rise (EPR) at the Juan Fernandez triple junction, and the Owen fracture zone (OFZ) with the Carlsberg (CaR) and Sheba (ShR) ridges at the Aden-Owen-Carlsberg (AOC) triple junction. For each of these three cases, the expected RRF triple junction does not exist because the transform fault arm of the triple junction has evolved into a divergent boundary. AF is Africa plate. AN is Antarctic plate. AR is Arabia plate. EU is Eurasia plate. IN is India plate. JF is Juan Fernandez microplate. NA is North America plate. NZ is Nazca plate. PA is Pacific plate. SO is Somalia plate. TeR is Terceira rift.

Figure 2. Geodynamic setting of the AOC triple junction between the Arabia, India and Somalia plates, with shallow seismicity between 1964 and 1998 (Engdahl et al., 1998; focal depth $<50 \mathrm{~km}$; magnitude $>3.9$ ) and all available earthquake focal mechanisms for the AOC triple junction (Dziewonski et al., 1981; Quittmeyer and Kafka, 1984). The Owen fracture zone (OFZ) is dextral. The Owen transform fault (OTF), which connects the Carlsberg and Sheba ridges, is sinistral. South of $15^{\circ} \mathrm{N}$, the southern OFZ is seismically quiet over $250 \mathrm{~km}$. Immediately east of the OFZ, solid symbols correspond to pickings of Early Tertiary magnetic anomalies 23 to possibly 28 identified beneath the Indus Fan (Royer et al., 2002; Chaubey et al., 2002). The location of the ophiolites emplaced along the Oman continental margin in Masirah Island and Ra's Madrakah at the $\mathrm{K} / \mathrm{T}$ transition is shown. Unlike the Semail ophiolites in northern Oman of Late Cretaceous age, these ophiolites correspond to an ancient oceanic crust of Late Jurassic age (Smewing et al., 1991; Peters and Mercolli, 1998; see Fournier et al., 2006 for a synthesis).

Figure 3. Velocity-space diagrams of the AOC triple junction. a. Mean India-Somalia and Arabia-Somalia velocity vectors calculated from DeMets et al. (1994), Fournier et al. (2001) and Reilinger et al. (2006) (solid lines and dots), and associated standard errors (light and dark grey beams, respectively). b. Possible stable RFF configuration with a completely flat velocity triangle. c. Possible stable RRR configuration with the mean velocity triangle and an oblique ridge at the Arabia-India boundary. 
Figure 4. Multibeam bathymetric map of the AOC triple junction acquired during the AOC cruise of the $R / V$ Beautemps-Beaupré (2006), with shallow seismicity and earthquake focal mechanisms. The map shows the axial rift and the northern flank of the Sheba Ridge, and the southern termination of the OFZ to the northeast. The polygons outline areas of topography that are smooth, rounded (convex upwards) with superimposed ridges and troughs (corrugations) oriented perpendicular to the ridge. These structures are interpreted as oceanic core complexes (or megamullions), as inferred for similar features studied in more detail elsewhere (e.g., Ohara et al., 2001; Searle et al., 2003; Cannat et al., 2006; Ildefonse et al., 2007). OOT is ocean-ocean transition (see text). Star is for location of Figure $5 \mathrm{~b}$.

Figure 5. a. Perspective view from the northwest of the western median rift developed at the Sheba Ridge axis. The rift is $30-40 \mathrm{~km}$ wide and $3000-3800 \mathrm{~m}$ deep. Away from the neovolcanic ridge, which marks the axis of spreading, the topography is controlled by riftward-dipping normal faults. b. Volcanoes and oceanic core complexes in the eastern part of the axial rift. Location in Figure 4. Colour scales in Figures 4 and 5 are different.

Figure 6. Free air and mantle Bouguer gravity maps of the AOC triple junction. Gravity data were acquired along the ship tracks with an original data spacing of $30 \mathrm{~m}$ along track and $17 \mathrm{~km}$ between tracks, and an accuracy of $0.02 \mathrm{mGal}$. The complete Bouguer gravity was computed by using a mean density contrast of $1840 \mathrm{~kg} \cdot \mathrm{m}^{-3}$ between the oceanic crust and water, and of $300 \mathrm{~kg} \cdot \mathrm{m}^{-3}$ between the crust and mantle. Dashed lines show location of profiles in Figure 10.

Figure 7. Perspective views of (a) the $\mathrm{N} 10^{\circ} \mathrm{E}$-trending $\mathrm{OFZ}$ offsetting the Owen Ridge over $12 \mathrm{~km}$ and (b) the Beautemps-Beaupré rift basin at the southern end of the OFZ bounded by $\mathrm{N} 70^{\circ} \mathrm{E}$ to $\mathrm{N} 90^{\circ} \mathrm{E}$ trending normal faults.

Figure 8. Structural map of the southern end of the OFZ. The OFZ terminates in the $50 \mathrm{~km}$ wide and $120 \mathrm{~km}$ long Beautemps-Beaupré Basin bounded by normal faults. Rifting was initiated in the transition zone between the young oceanic crust generated at the Sheba Ridge and the old oceanic crust of the Owen Basin. By analogy with the ocean-continent transition (OCT) located westward in the Gulf of Aden, this transition is more properly named "oceanocean transition" (OOT) than pseudofault. Strictly speaking, a pseudofault is defined as the fossil trace ("propagator wake") made by the propagation of a segment of spreading ridge at 
the expenses of the retreating adjacent segment (Hey, 1977; Kleinrock and Hey, 1989; Kruse et al., 2000; Briais et al., 2002). Here, the OOT corresponds to the transition between a rifted, old oceanic crust formed at a now disappeared spreading ridge and a young oceanic crust newly formed at the Sheba Ridge. The Beautemps-Beaupré rift propagated westward in the oceanic crust of the northern flank of the Sheba Ridge. To the west of the basin, E-W faults in the oceanic crust crosscutting faults and dykes generated at the Sheba Ridge suggest that the extensional deformation is propagating westward. Minor normal faults are also observed to the east of the OFZ on the Indian plate. Numerous landslides probably triggered by earthquakes are observed along the slopes.

Figure 9. High-resolution (3.5 kHz) seismic reflection profiles across the Beautemps-Beaupré Basin. The profiles are aligned on the northern bounding fault of the basin. The blow-up on profile AOC3 illustrates the downward increasing offset of a synsedimentary normal fault. $\mathrm{B}^{3}$ is Beautemps-Beaupré Basin. Location of profiles is shown in inset.

Figure 10. Free air gravity and bathymetry profiles across the Beautemps-Beaupré Basin and the northern flank of the Sheba Ridge. Profiles are oriented along N27 $\mathrm{E}$ and aligned on the ridge axis. Location of profiles is shown on Figure 6.

Figure 11. Sketch of successive stages of evolution of the triple junction since $\sim 8$ Ma with corresponding velocity triangle and stability of the triple junction. The configuration of the junction before (a) and after (b) the development of the pull-apart basin is shown, and a possible RRR configuration (c) in the near future is proposed. The change in configuration of the triple junction was probably induced by a regional reorganization of plate velocities and directions 8-10 million years ago, which initiated the active strike-slip fault and the pull-apart basin. The dashed lines represent velocities which leave the geometry of the boundaries unchanged. 


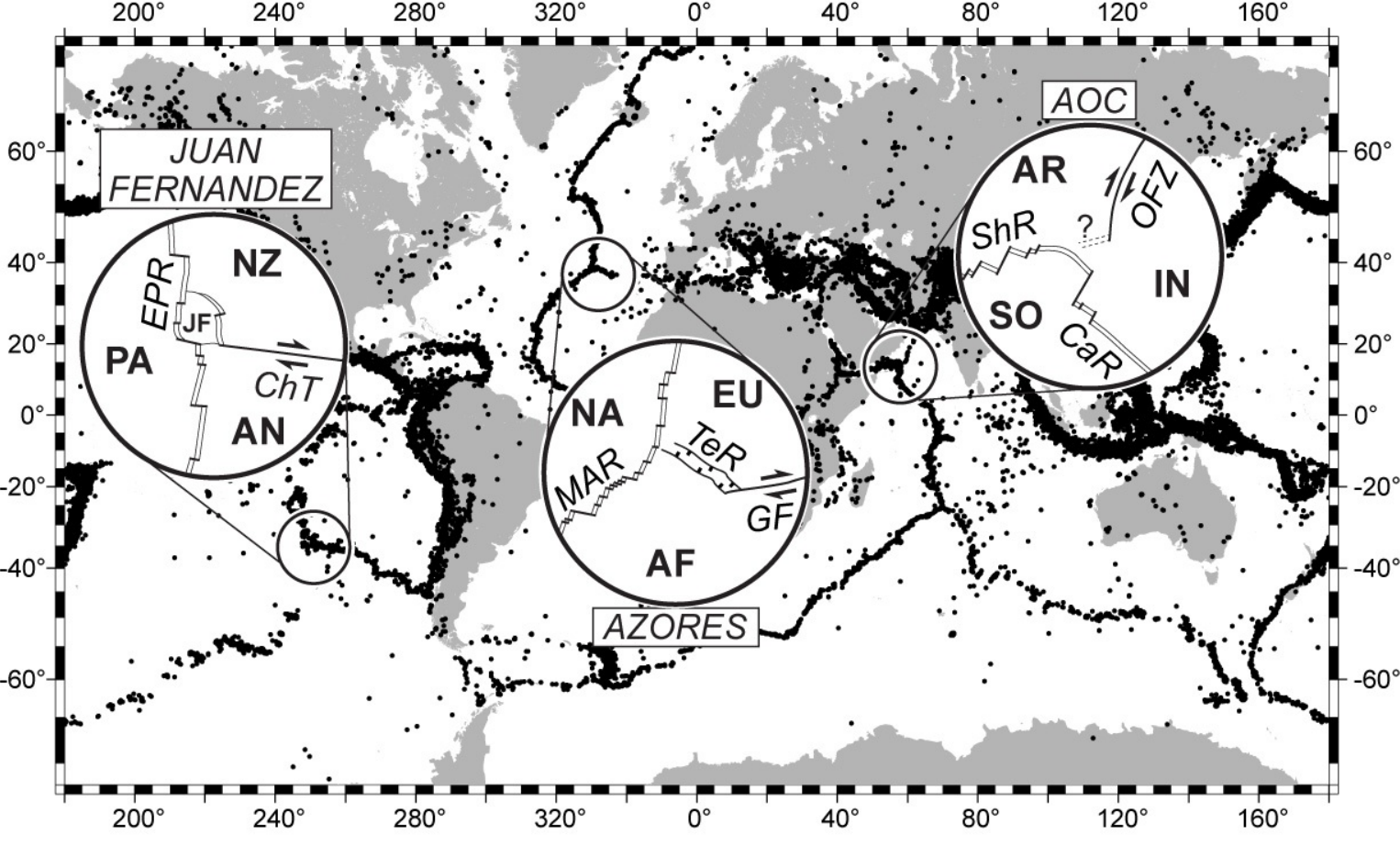

Figure 1 



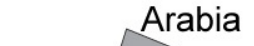

(A)

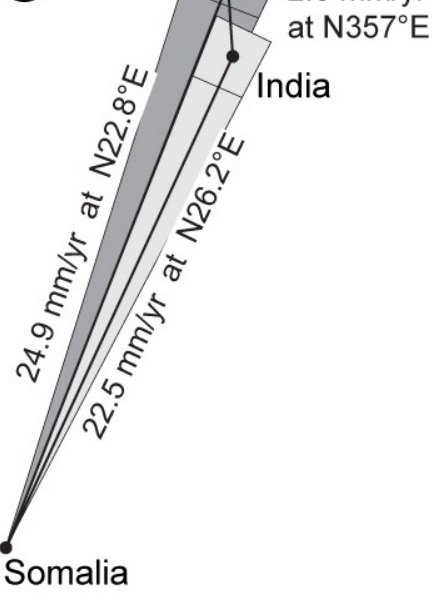

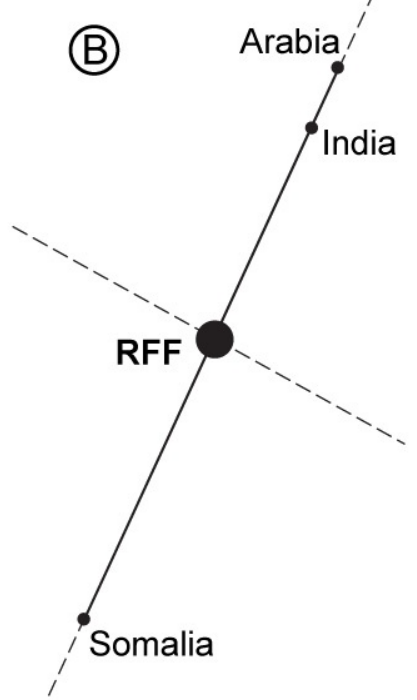

(C)

Arabia

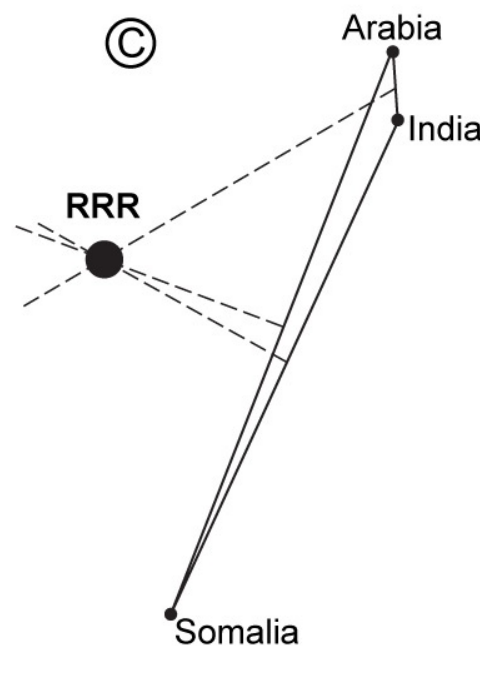

Figure 3 


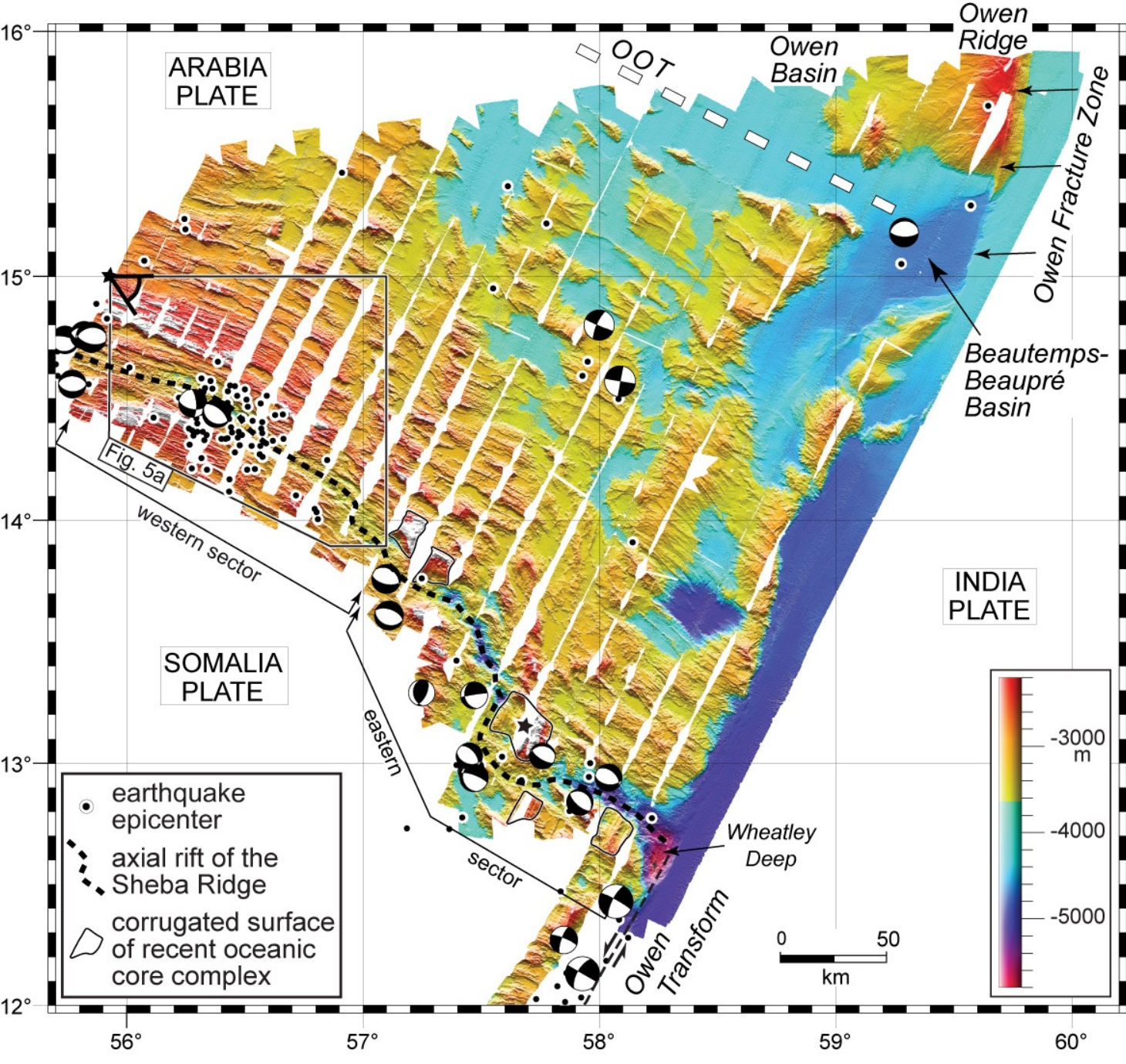

Figure 4 


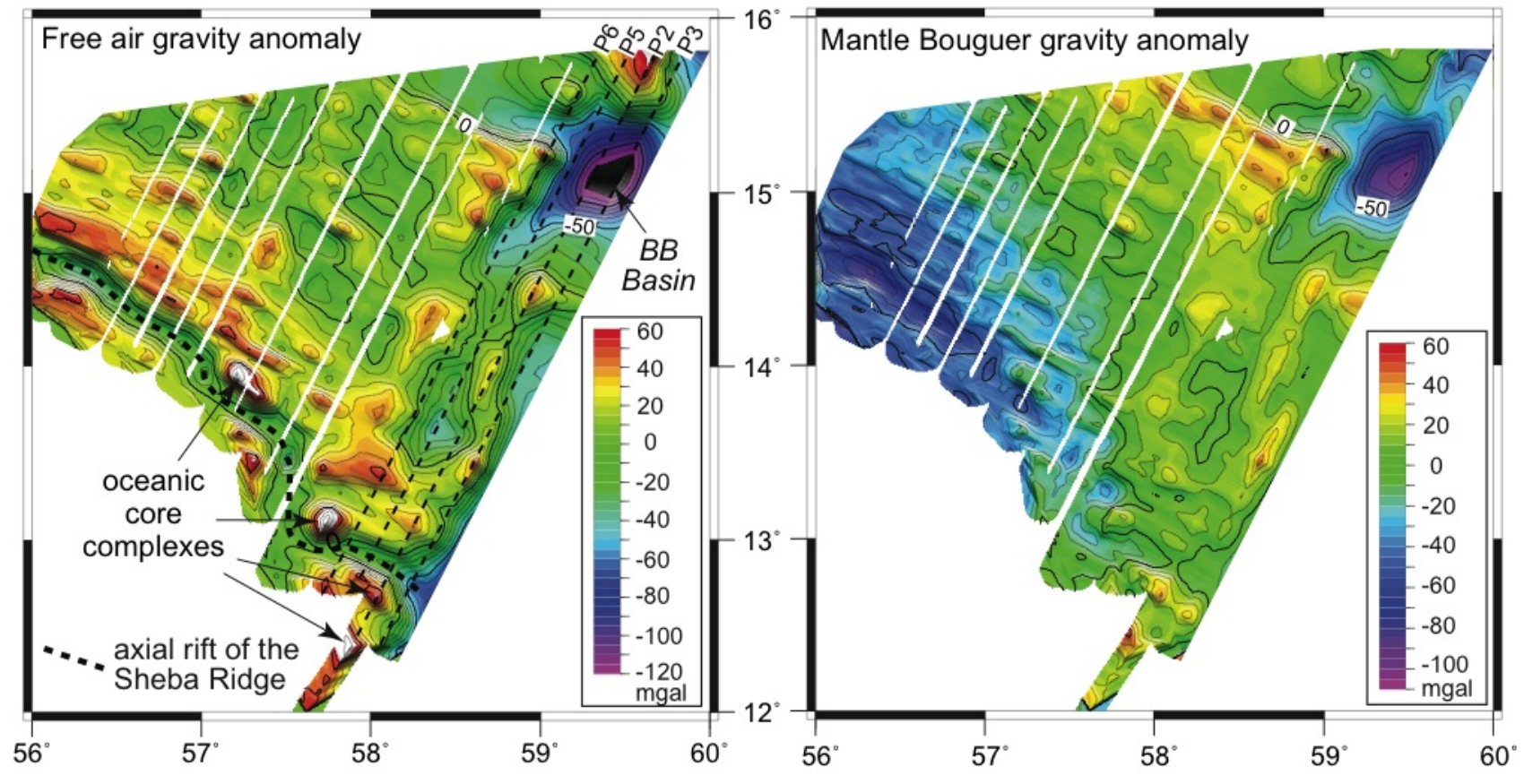

Figure 6 

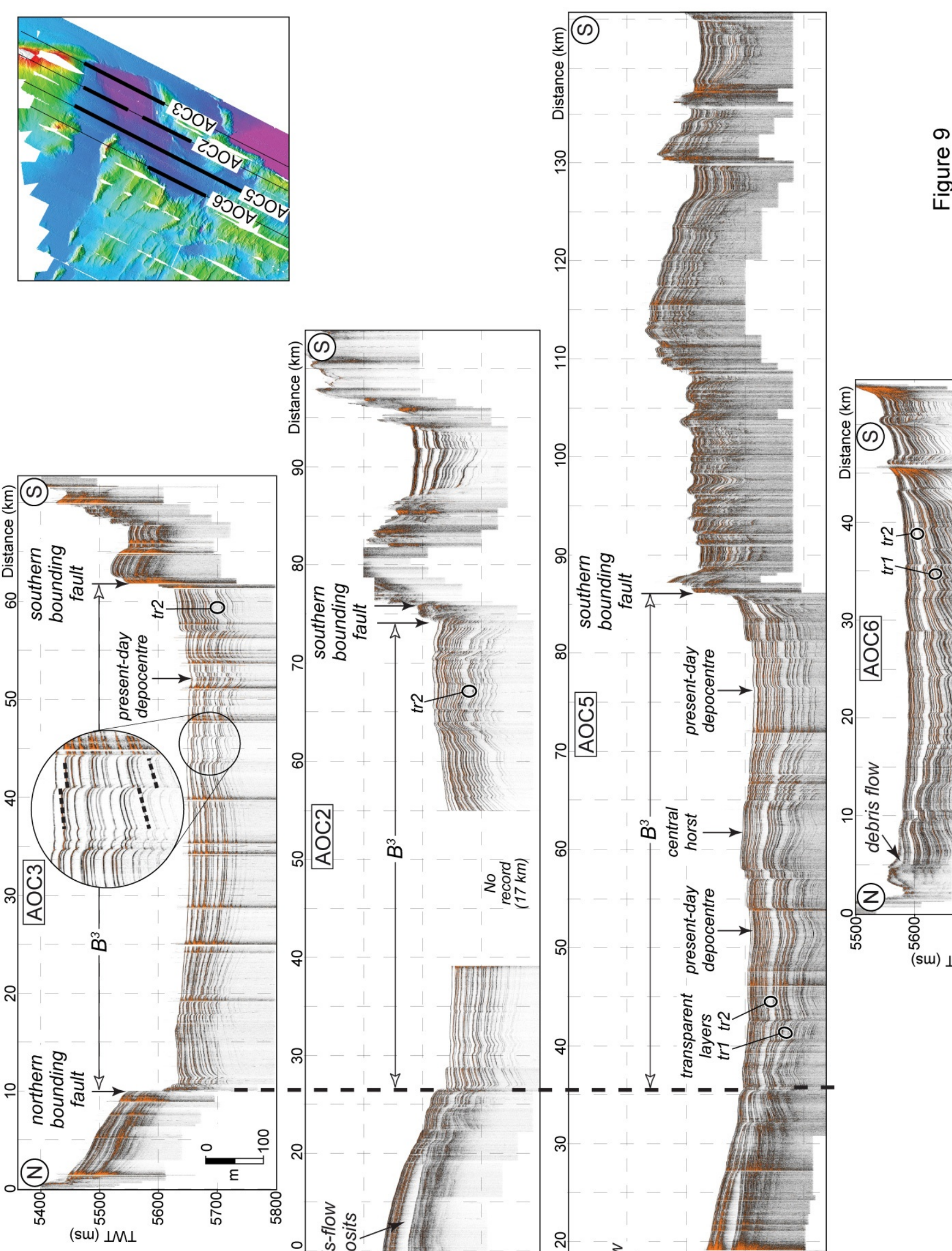

은
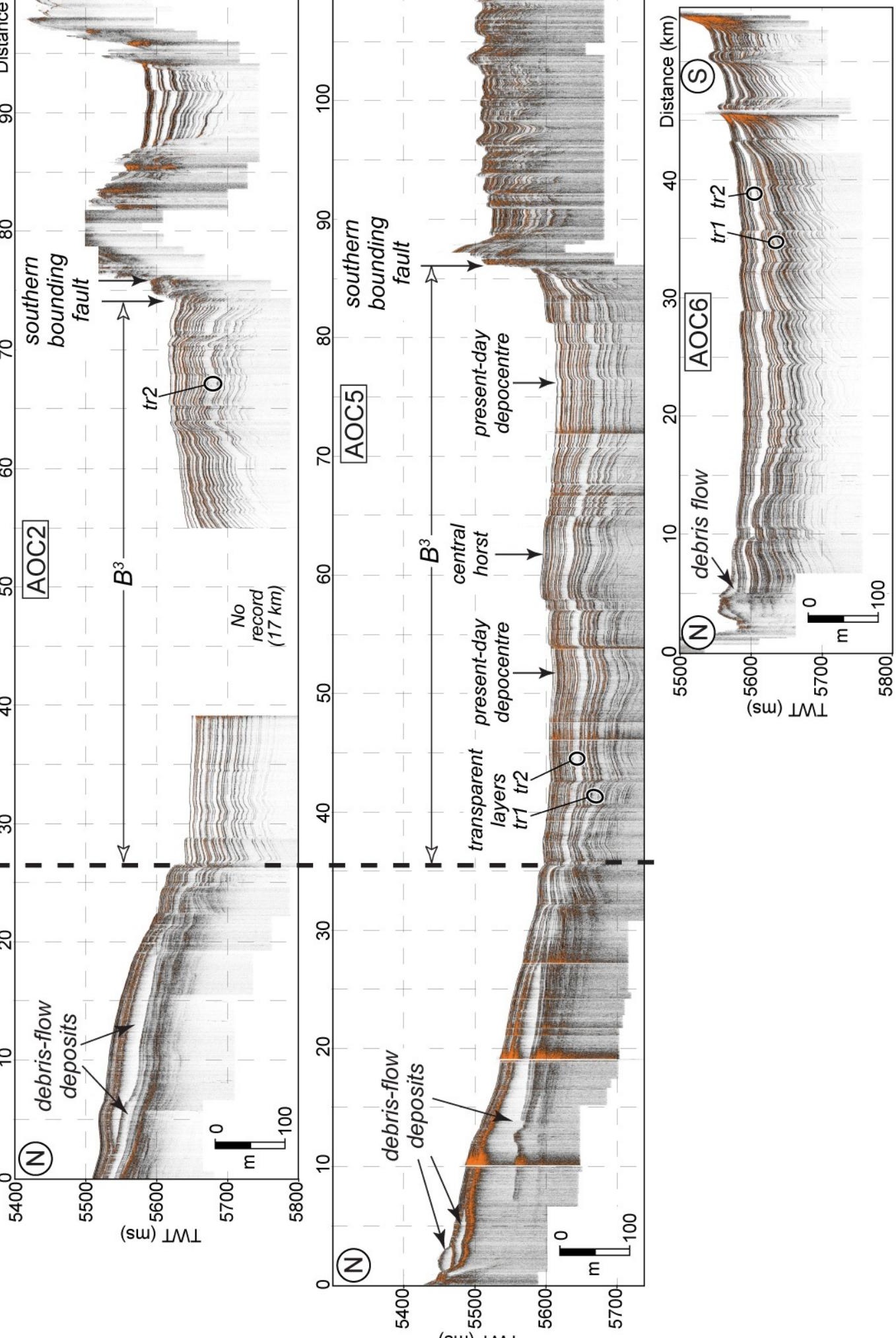

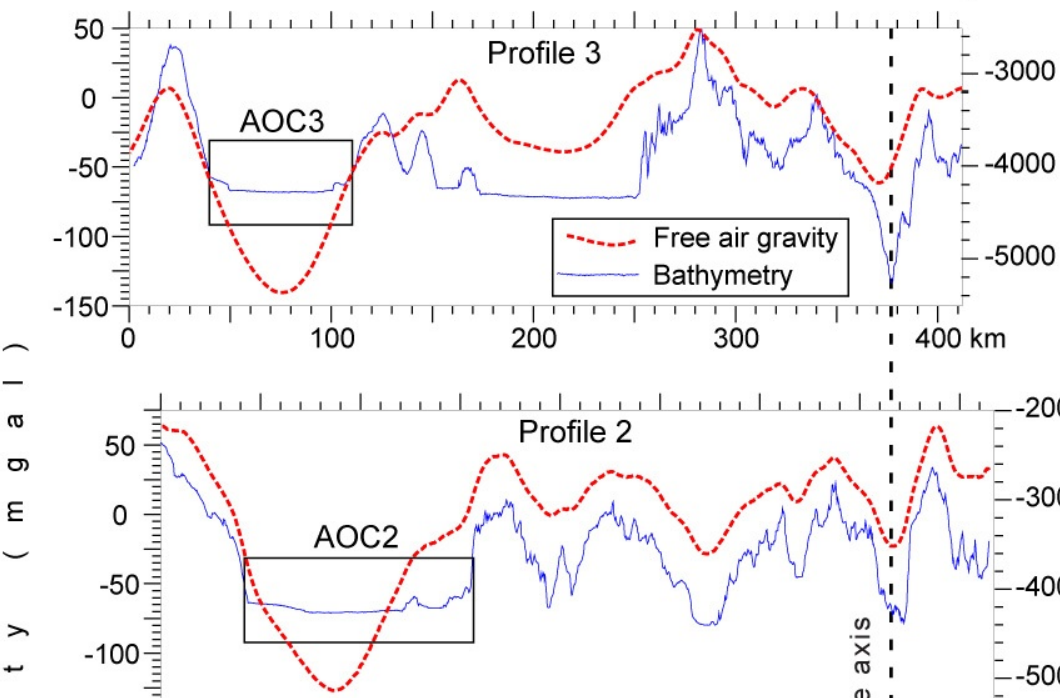

1,11
Profile 2

ס)

$\varepsilon$

$-150$

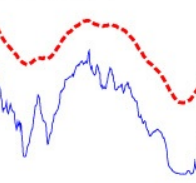

$+$

๘

$-$

ఠ)

$e^{-100-}$

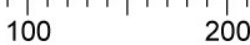

$300, \frac{1}{11}, 400 \mathrm{~km}$

$--4000$

\begin{tabular}{l} 
ס \\
D \\
0 \\
- \\
\hline
\end{tabular}

$\pi$

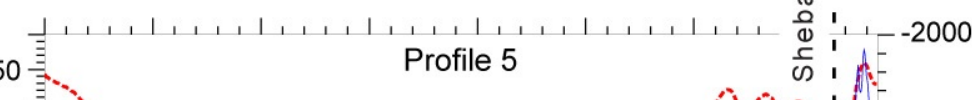

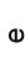

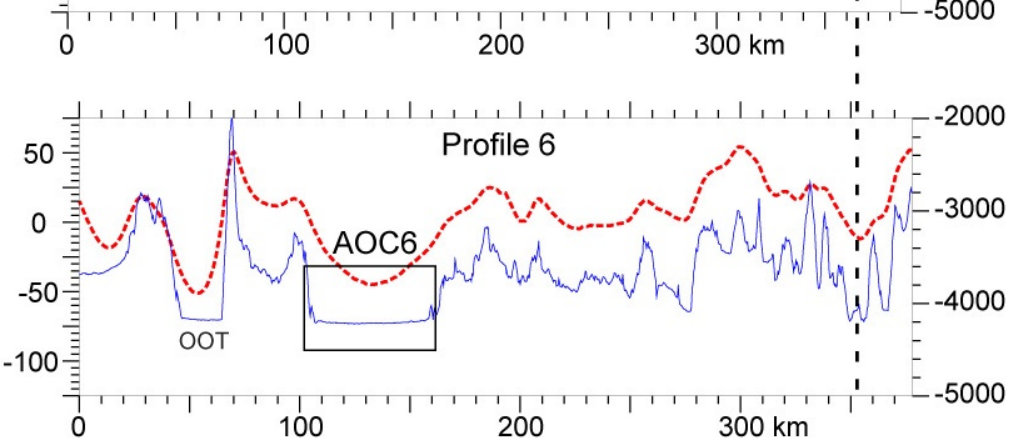

Figure 10 
5 ARABIA

$10^{\circ}$ SOMALIA
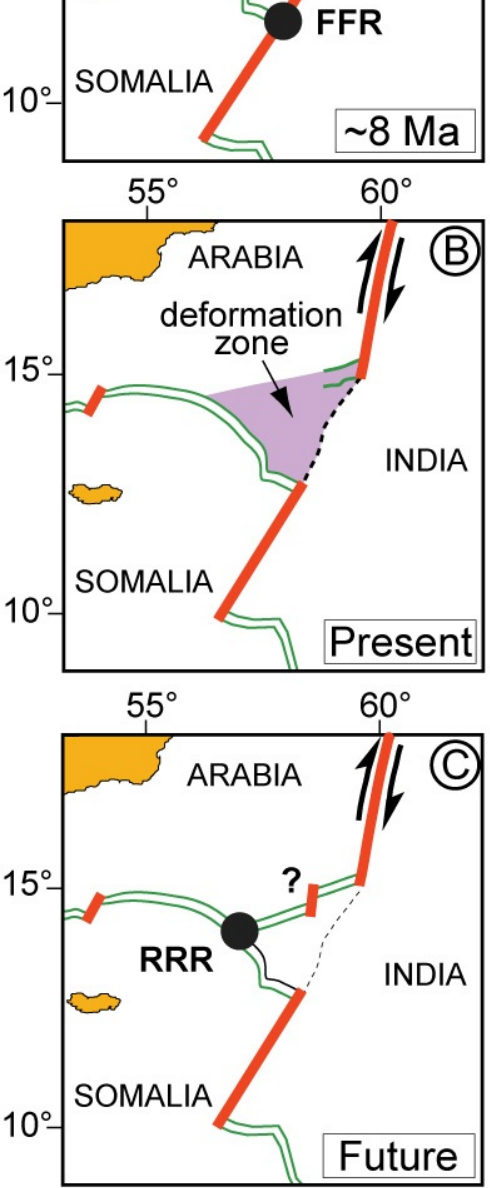
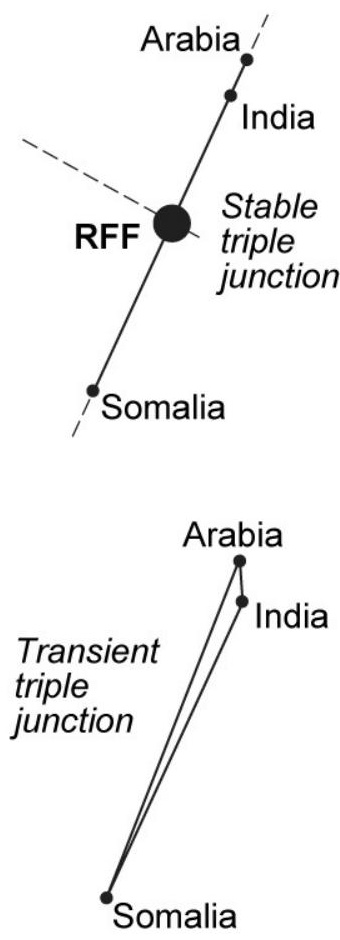

Stable Arabia triple junction
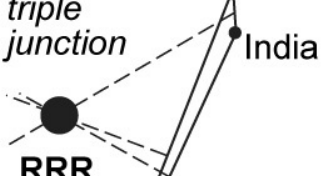

\section{RRR}

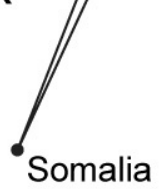

Figure 11 